www.jmscr.igmpublication.org

Impact Factor (SJIF): 6.379

Index Copernicus Value: 79.54

ISSN (e)-2347-176x ISSN (p) 2455-0450

crossrefDOI: https://dx.doi.org/10.18535/jmscr/v6i12.106

Journal Of Medical Science And Clinical Research

\title{
Illustrated Story Book for Caries Preventive Education
}

\author{
Authors \\ Hermien Nugraheni $^{*}$, Triwiyatini ${ }^{2}$, Sadimin $^{3}$, Aryadiva Prayoga ${ }^{4}$, Wanda Nur Aida ${ }^{5}$, \\ Nugraheni Widyastuti ${ }^{6}$, Waffiyatul Huda ${ }^{7}$ \\ ${ }^{1,2,3}$ Lecturers of Ministry of Health Health Polytechnic, Semarang, Indonesia \\ ${ }^{4,5,6,7}$ Students of Ministry of Health Health Polytechnic, Semarang, Indonesia \\ *Corresponding Author \\ Hermien Nugraheni \\ Email: hermienprajoga@gmail.com
}

\begin{abstract}
Background: The current phenomenon, children of elementary school age generally has a high risk of caries, because of their habit on consuming cariogenic foods and drinks (such as candy, chocolate, biscuits, etc.). Dental caries can be prevented early by maintaining dental and oral hygiene, as well as avoiding foods and beverages that contain cariogenic ingredients. The purpose of this study was to find out whether there was an impact of using illustrated storybook media on caries prevention education by avoiding cariogenic foods in elementary school students.

Method: The research's design was quasi-experimental with a non-equivalent control group design. The intervention and control group were elementary students in the working area of Kedungmundu Community Health Center, Semarang City. Data analysis included univariate and bivariate analysis. To find out whether there is a difference in knowledge before and after the intervention, the Wilcoxon test was applied. To find out whether there were differences in knowledge between those who received the intervention and those who did not receive the intervention, the Mann Whitney test was employed.

Result: The data analysis showed that the differences in knowledge before and after getting an education about prevention of caries by avoiding cariogenic food in students in the intervention group had a $p$-value = 0.000. The difference in knowledge of students in the group who got and who did not get the educational intervention, the $p$-value $=0.000$.

Conclusion: There are differences in knowledge before and after getting an education about prevention of caries by avoiding cariogenic foods using illustrated storybook media. There is a difference of knowledge in students who get and who do not get an educational intervention.

Keywords: Education, Illustrated Storybook, Cariogenic.
\end{abstract}

\section{Background}

Oral and dental health is one of the critical things in human life. Dental and oral health problems still need to be considered, because dental and oral diseases are still a problem that is often complained of by the community, one of the diseases that many people suffer especially in children is dental caries (Talibo, Mulyadi , \& Bataha 2016; Pratiwi, 2013).

The current phenomenon of children in 
elementary school age generally has a high risk of caries, because of their habit on consuming cariogenic foods and drinks (such as candy, chocolate, biscuits, etc.) (Rosidi, Haryani, and Adimayanti E, 2013; Alifiani, 2017). Children at this age still depend on the parents in maintaining healthy teeth and mouth. When parents do not pay attention to their children's oral and dental health and do not teach their children to keep healthy teeth by brushing their teeth, the children will not take care of their teeth. Besides children also do not understand and know how to maintain proper oral and dental health (Ernawati, 2011).

The prevalence of dental caries in children according to the World Health Organization (WHO) in 2003 states that the incidence of caries in children is still at $60-90 \%$. Children at this age are susceptible to the growth and development of dental caries because they have snacks and food habits both at school and at home without knowing whether the food is cariogenic or not (Tamrin, \& Afrida, 2014). Foods that are easily attached to the surface of the tooth will accelerate the process of dental caries (Doichinova, Bakardjiev, \& Peneva, 2015).

Dental caries can be prevented early, namely by maintaining dental and oral hygiene, as well as conducting a scale examination 6 months to 1 year, besides prevention can also be done by paying attention to eating patterns. Our diet should avoid foods and beverages that contain cariogenic ingredients, namely foods or drinks that contain sugar or sucrose and foods that are soft and easily attached to teeth (chocolate, biscuits, etc.) because it can cause demineralization of the enamel layer (Doichinova, Bakardjiev, \& Peneva, 2015). Sweet foods if long left in the mouth will damage the teeth, but all that can be prevented by brushing your teeth regularly or by gargling water after consuming sweet foods (Ratnaningsih, 2013).

Semarang City Health Profile in 2015 showed that at the age of 5-14 years the proportion of children affected by dental caries reached $23.97 \%$, whereas at the age of $15-44$ years the percentage of dental caries reached $49.03 \%$.

Efforts to improve dental and oral health include promotive, preventive, curative, and rehabilitative efforts that can be enhanced by community participation (Desi Andriyani, 2013; Nyoman, Supariani, \& Ratmini NK, 2016). One of the efforts to minimize the existing morbidity is preventive, through health promotion. Health promotion can be done by providing health education (Parmar et al., 2016; Veiga et al., 2016). This is intended to provide sufficient knowledge and understanding of dental health problems, especially dental caries and how to prevent them by avoiding eating cariogenic foods in elementary school children (children aged 612 years) (Montero, Camañas, \& Peralta, 1991).

A lot of media can be done in providing health education to elementary school children, such as leaflets, videos, films, puzzle games, snake ladder games, and storybooks (Hamdalah, 2013; Tandilangi, Mintjelungan, \& Wowor, 2016). Other media that can be used are illustrated story books. Primary school children have a high imagination, so that illustrated story books are allegedly able to increase children's imagination (Adipta \& Hasanah, 2017; Eni Suryaningsih \& Laila, 2013). If the invention is active, the child easily understands the material presented in the book. Thus, the child will also do the things that are conveyed in the book. Illustrated storybooks about oral and dental health have been circulating in the community, but research into the effectiveness of illustrated storybooks about preventing caries by avoiding cariogenic foods has never been done.

The purpose of this study was to find out whether there was an impact of education using illustrated storybook media on caries prevention knowledge by avoiding cariogenic foods in elementary students.

\section{Method}

The research design used was quasi-experimental with a non-equivalent control group design. The intervention and control group were elementary 
students in the working area of Kedungmundu Community Health Center, Semarang City. Interventions were given to elementary school students in one school, and another school was not given a response that was used as a control group. Intervention activities carried out on students are education using illustrated story books.

To find out whether there were differences in knowledge before and after the intervention, the control group, and the intervention group because the data were abnormally distributed using the Wilcoxon test. The data tested were pre and postintervention knowledge. To find out whether there is a difference in knowledge between those who received the intervention and those who did not receive the intervention, because the data were not normally distributed using the Mann Whitney test. The data tested is delta knowledge.

\section{Result}

This research type is quasi-experimental research conducted in grade 3 students of elementary schools in the working area of Kedungmundu Community Health Center, Semarang City with materials avoiding cariogenic foods. There were 250 respondents from 8 public and private primary schools. Furthermore, the elementary schools were divided into intervention groups and control groups as follows:

Table 1 List of Primary Schools serving as Intervention and Control Groups

\begin{tabular}{llll}
\hline \multicolumn{2}{l}{ Intervention group } & \multicolumn{2}{c}{ Control group } \\
\hline No & $\begin{array}{c}\text { The name of Primary } \\
\text { school }\end{array}$ & No & $\begin{array}{c}\text { The name of Primary } \\
\text { school }\end{array}$ \\
\hline 1 & Mangunharjo & 1 & Sendangmulyo 1 \\
\hline 2 & Sambiroto 2 & 2 & Sendangmulyo 2 \\
\hline 3 & Sambiroto 3 & 3 & Sendangmulyo 3 \\
\hline 4 & Kedungmundu & 4 & Sendangmulyo 4 \\
\hline
\end{tabular}

The description of students' knowledge before and after getting the education about prevention of caries by avoiding cariogenic foods using media illustrated storybooks is as follows:
Table 2. Knowledge of students before and after getting an education

\begin{tabular}{|l|c|c|c|c|c|}
\hline \multirow{2}{*}{ No } & \multirow{2}{*}{$\begin{array}{c}\text { Student's } \\
\text { Knowledge }\end{array}$} & \multicolumn{3}{|c|}{ Intervention Group } \\
\cline { 3 - 6 } & & \multicolumn{2}{|c|}{ Before } & \multicolumn{2}{c|}{ After } \\
\cline { 3 - 6 } & & $\mathrm{f}$ & $\%$ & $\mathrm{f}$ & $\%$ \\
\hline 1 & Good & 94 & 75 & 119 & 95 \\
\hline 2 & Satisfactory & 30 & 24 & 6 & 5 \\
\hline 3 & Poor & 1 & 1 & 0 & 0 \\
\hline & Amount & 125 & 100 & 125 & 100 \\
\hline
\end{tabular}

From table 2 above, it can be seen that before the intervention in the form of caries prevention education, knowledge among $75 \%$ of students in the intervention group was useful, $24 \%$ of students were satisfactory and $1 \%$ students were poor. And after getting intervention students with sound knowledge becomes $95 \%$ and student with adequate knowledge is $5 \%$.

The description of students' knowledge before and after getting the education about prevention of caries by avoiding cariogenic foods without using illustrated storybooks media is as follows: Table 3. Knowledge of students before and after getting the education without using pictorial story book media

\begin{tabular}{|l|c|c|c|c|c|}
\hline \multirow{2}{*}{ No } & \multirow{2}{*}{ Student's } & \multicolumn{4}{|c|}{ Control Group } \\
\cline { 3 - 6 } & Knowledge & \multicolumn{2}{|c|}{ Before } & \multicolumn{2}{c|}{ After } \\
\cline { 3 - 6 } & & $\mathrm{f}$ & $\%$ & $\mathrm{f}$ & $\%$ \\
\hline 1 & Good & 92 & 74 & 92 & 74 \\
\hline 2 & Satisfactory & 31 & 25 & 31 & 25 \\
\hline 3 & Poor & 2 & 1 & 2 & 1 \\
\hline & Amount & 125 & 100 & 125 & 100 \\
\hline
\end{tabular}

From table 3 above, it can be seen that before the intervention in the form of caries prevention education without illustrated storybook media, knowledge among $74 \%$ of students in control group was good, $25 \%$ of students were satisfactory and $1 \%$ students were poor. And after getting intervention without illustrated storybook media in the control group, the condition was not changed. The students with good knowledge still $74 \%$, $25 \%$ of students were satisfactory and $1 \%$ students were poor.

The differences in students' knowledge before and after the intervention in the form of education about prevention of caries by avoiding cariogenic foods using the illustrated storybook media with the Wilcoxon test are as follows : 
Table 4. Differences in students' knowledge before and after the intervention

\begin{tabular}{|c|c|}
\hline \multicolumn{2}{|c|}{ Test Statistics } \\
\hline & $-6.444^{\mathrm{a}}$ \\
\hline $\mathrm{Z}$ & .000 \\
\hline Asymp. Sig. (2-tailed) &
\end{tabular}

a. Based on negative ranks.

b. Wilcoxon Signed Ranks Test

In table 4 it can be seen that the value of $p=$ 0.000 . This means that there are differences in knowledge before and after getting an education about prevention of caries by avoiding cariogenic foods in students in the intervention group.

The difference in knowledge of students who received and who did not get the intervention in the form of education about prevention of caries by avoiding cariogenic foods using illustrated storybook media using the Mann Whitney test (because of abnormal distribution) was as follows:

Table 5. The difference in knowledge of students who get and who do not get an education

\begin{tabular}{|c|c|c|c|}
\hline \multicolumn{4}{|c|}{ Ranks } \\
\hline Treatment & $\mathrm{N}$ & Mean Rank & Sum of Ranks \\
\hline Intervention & 125 & 148.82 & 18602.50 \\
\hline Control & 125 & 102.18 & 12772.50 \\
\hline Total & 250 & & \\
\hline \multicolumn{4}{|c|}{ Test Statistics } \\
\hline \multicolumn{3}{|c|}{ Mann-Whitney U } & 4897.500 \\
\hline \multicolumn{3}{|c|}{ Wilcoxon W } & 12772.500 \\
\hline \multicolumn{3}{|c|}{$\mathrm{Z}$} & -5.222 \\
\hline \multicolumn{3}{|c|}{ Asymp. Sig. (2-tailed) } & .000 \\
\hline
\end{tabular}

a. Grouping Variable: Treatment

In table 5 it can be seen that the value of $\mathrm{p}=$ 0,000 . This means that there is a difference in knowledge among students who get and who do not get the education about caries prevention by avoiding cariogenic foods using illustrated story books.

\section{Discussion}

Primary school students are students who are the fastest in capturing and transferring knowledge obtained from school for families and communities. Therefore, early health education to elementary school students is an initial step toward building a healthy community (Rara, 2017; Arianto \& Shaluhiyah, 2014).

Efforts to improve dental and oral health include promotive, preventive, curative, and rehabilitative efforts that can be enhanced by community participation. One attempt to minimize the existing morbidity is precautionary, employing health promotion. Health promotion can be done by providing health education. This is intended to provide sufficient knowledge and understanding of dental health problems, especially dental caries and how to prevent them by avoiding eating cariogenic foods in elementary school children (children aged 6-12 years).

Students at elementary school tend to prefer to read if the contents of the book have compelling images, even more like reading picture books. Illustrated storybooks are stories written in a light language style, tend to be in a chat style, equipped with images that are a unity of the story to convey specific ideas (Permana, 2017; Ngura, 2018). Besides being interesting, illustrated storybooks also have several benefits, including being able to help develop children's emotions, obtain pleasure, help children learn about the world and to stimulate imagination (Roslina, 2017). Illustrated storybook media about dental health for elementary schools has not been widely developed, making this research has its advantages, namely by developing illustrated storybooks about caries prevention by avoiding cariogenic foods that can be integrated into activities and subjects concerning for self and environment. (Hamdalah,2013).

This illustrated storybook about dental and oral health is very necessary to be developed, considering the high rate of caries in primary school-age children due to low knowledge and influence on actions that result in dental caries 
of school-age children, such as brushing teeth not yet true and sweet food consumption habits are attached. ${ }^{(22,23)}$ The advantages of illustrated storybooks that are easy to use and can be used in many ways for teaching levels are expected to make students more interested in learning about dental and oral health. Besides, illustrated storybooks can stimulate imagination and help children in enriching imagination, because images in storybooks contain stories.

Illustrated storybooks about dental and oral health are expected to foster a sense of love for reading to students. Another goal is for students to know and understand the positive messages contained in it, and to be able to apply a series of oral and dental health efforts in real life (Nalli et al., 2016).

\section{Conclusion}

There were differences in knowledge before and after getting an education about prevention of caries by avoiding cariogenic food using pictorial storybook media for students in the intervention group, with $\mathrm{p}$-value $=0.000$. There is a difference of knowledge in students who get and who do not get an education about prevention of caries by avoiding cariogenic foods using illustrated storybook media with p-value $=0.000$.

\section{References}

1. Adipta H, Hasanah M, Dasar P, Malang PN. Pemanfaatan Buku Cerita Bergambar. Journal Pendidikan Teori Penelitian, dan Pengembangan . 2016;1(5):989-92.

2. Arianto A, Shaluhiyah Z. Perilaku Menggosok Gigi pada Siswa Sekolah Dasar Kelas V dan VI di Kecamatan Sumberejo. Journal Promosi Kesehatan Indonesia. 2014; 9 (2) .

3. Alifiani H. Hubungan Kebiasaan Gosok Gigi dan Konsumsi Makanan Kariogenik Dengan Kejadian Karies Gigi Pada Anak Usia Sekolah. Faletehan Health Journal. 2017 Aug 19;4(4):228-32.
4. Doichinova L, Bakardjiev P, Peneva M. Assessment of food habits in children aged 6-12 years and the risk of caries. Biotechnology \& Biotechnological Equipment. 2015 Jan 2;29(1):200-4.

5. Desi Andriyani. Media komunikasi dalam keberhasilan promosi kesehatan gigi dan mulut. Jurnal Keperawatan. 2013;IX(2):158-63.

6. Eni Suryaningsih dan Laila F. Pengembangan Buku Cerita Bergambar tentang Mitigasi Bencana Erupsi Gunung Api untuk Siswa SD. e-ISSN : 2503-3530. 2013;2(2):110-7.

7. Ernawati, Arwani. Hubungan Antara Perilaku Mengkonsumsi Makan Makanan Manis Dan Perilaku Menggosok Gigi Dengan Kejadian Karies Gigi Pada Anak Tk Pertiwi 37 Gunung Pati. 2011;4(183193):1-12.

8. Hamdalah A. Efektivitas Media Cerita Bergambar dan Ular Tangga dalam Pendidikan Kesehatan Gigi dan Mulut Siswa SDN 2 Patrang Kabupaten Jember. J Promkes. 2013;1(2):118-23.

9. Montero J, Camañas G, Peralta B, R. Oral Health Habits in Primary and Secondary School Children. 1991;1076-80.

10. Nalli S, Bindiganavale SR, Chowdary BU. A study of oral health promotion activities in India. International Journal Of Community Medicine And Public Health. 2017 Jan 5;3(8):2270-4.

11. Ngura ET. Pengembangan Media Buku Cerita Bergambar untuk Meningkatkan Kemampuan Bercerita dan Perkembangan Sosial Anak Usia Dini. Jurnal Ilmu Pendidikan Citra Bakti. 2018;5(1):6-14.

12. Nyoman N, Supariani D, Ratmini NK. Efektivitas Penyuluhan untuk Peningkatan Pengetahuan Kesehatan gigi dan Mulut Siswa Kelas V SDN 16 Kesiman Denpasar Timur. Jurnal Kesehatan Gigi. 2016;4(1):35-42. 
13. Pratiwi, Eka, P. Hubungan persepsi tentang karies gigi dengan kejadian karies gigi pada calon pegawai kapal pesiar yang datang ke dental klinik di Denpasar tahun 2012. Public Health and Preventive Medicine Archive. 2012;1(1).

14. Parmar P, Radha G, Pallavi S, Nagashree S. Promoting oral hygiene and health through school. International Journal of Oral Health Science. 2016;6(70):7.

15. Preethi S. Dental health education and the role of teachers in imparting oral health education in Indian schools. Journal of Education and Ethics in Dentistry. 2015 Jul 1;5(2):57.

16. Permana A. Efektivitas Penggunaan Media Buku Cerita Bergambar dalam Penanaman nilai-nilai Moral Siswa SD Kelas Rendah. Jurnal Penelitian Pendidikan. 2017;4 (November).

17. Rara G. Hubungan Tingkat Pengetahuan dengan Perilaku Pemeliharaan Kesehatan Gigi Siswa Sekolah Dasar. Journal of Health Education. 2017;2(1):39-46.

18. Rosidi A, Haryani S, Adimayanti E. The Relationship of Food Cariogenic Consumption and Genesis Dental Caries in Children At Sdn 1 Gogodalem Bringin District. 2013.

19. Ratnaningsih T. Hubungan Pola Makan Dengan Kejadian Karies Gigi Pada Anak Usia 7-9 Tahun. Jurnal Ilmu Kesehatan Bhamada. 2013;7(2).

20. Roslina. The Effect of Picture Story Books on Students' Reading Comprehension. Advanced Language Literature Study. 2017;8(2):213.

21. Talibo RS, Mulyadi M, Bataha Y. Kebiasaan Menggosok Gigi Dengan Kejadian Karies. e- Keperawatan. 2016;4.

22. Tamrin M, Afrida MJ. Dampak konsumsi makanan kariogenik dan kebiasaan menyikat gigi terhadap kejadian karies gigi pada anak sekolah. Journal of pediatric nursing. 2014 Jan;1(1):014-8.

23. Tandilangi M, Mintjelungan C, Wowor VNS. Efektivitas dental health education dengan media animasi kartun terhadap perubahan perilaku kesehatan gigi dan mulut Siswa SD Advent 02 Sario Manado. e-GiGi. 2016;4(2):106-10.

24. Veiga NJ, Pereira CM, Ferreira PC, Correia IJ. Prevalence of dental caries and fissure sealants in a Portuguese sample of adolescents. PloS one. 2015 Mar 24;10(3):e0121299. 